\title{
Community building as an educational task
}

\section{KEYWORDS}

individualisation, education, democracy, community

\begin{abstract}
Waldemar Segiet, Community building as an educational task. Culture - Society - Education no. 2(18) 2020, Poznań 2020, pp. 41-53, Adam Mickiewicz University Press. ISSN 2300-0422. DOI 10.14746/kse.2020.18.2.2.
\end{abstract}

Along with the description of contemporary societies, including the indication of clear tendencies towards "individualisation" of lifespan, focusing on subjects that observe themselves with reflection, an issue appears regarding the creation of a community, including the educational one. A peculiar outline of the reflexive modernity is recognised on the basis the ways how individuals achieve social integration.

Despite the differentiating forms of social and cultural life, the foundation of the accomplishment of self and the society, is still "community", which constitutes an encouragement to enter the issue of social (dis)integration, an inspiration allowing to bestow a defined sense on democracy, and socialization processes. Therefore, the need to consider the issues of communities arises, including their confirmation in education.

To present a path for social integration, with the full awareness that in modern societies the "common good" ideal is being lost, one should be accompanied by indications regarding education itself. One may reduce them to how the community constituted due to and within education, ensured the integration of all entities concerned, and helped accomplish democracy. 


\section{Introduction}

I am constructing a particular point of view regarding (post)modernity and education, in which the dominant reference is to be the educational community. On the other hand, the rationale for thinking of a community, remaining in a constant process of coming-to-be, would be best expressed by the following quotes:

Man may become a man only due to human community however at the same time, the human community is a necessary condition for realising the particular case of the idea of manhood (Paul Natorp).

People seek communities, but of such nature, that provide the feeling of being together and satisfying the hunger of emotional belonging, they do not enforce more serious obligations [...]. This way, the power of the social [...] is announcing itself, an informal centrality, which ensures the survival in the society (Michel Maffesoli).

In the analyses of reality, the shape of which is forming itself within the processes of clashing of various social practices; in the ways of presenting the individual interested in creating own life via practice - the „community” emerges. Community appears as the foundation of realising self and the society. It constitutes the encouragement of entering the issue of social (dis)integration. It inspires our cognition - one would like to add, a cognition that remains in a strict relation with the individual and communal wisdom.

Obviously, the very reference to the selected quotes, while favouring mobilisation directed at promoting the „common good” ideal, does not suffice. Struggling for cooperation between individuals, with the premise of reason of the common good demands of social reality instances (not of idealised reality).

Particularly, in relation to the described reality, indications are made towards situations of competition and rivalry, everyone against everyone, situations where the private becomes saint (Środa, 2003: 256). The meaning of the shaping of community consciousness is constituted by turning attention to the transparency of the examined reality, and pointing at the suggestive rhetoric in recognitions leading e.g. to „society at a turning point” („społeczeństwo na zakręcie”) (Marody, 2019).

Explaining, to some degree, due to particular, simultaneously suggestive illustrations of our society (based by authoritative diagnoses), I intend to highlight that I perceive the sense of the selected references in the possibility of formulating a peculiar conclusion on their basis.

Therefore, the analysis of society transformations makes us more sensitive to hazardous phenomena (not only from the individual viewpoint). It liberates the consciousness of the difficulties in democratising the social life. It indicates the 
need of expanding the areas of social practices interested in social engagement, agreement, collaboration and construction of networks of being together.

Here appears the task, which, for me, is the attempt to create an insight into the social reality of reflective modernity, an attempt made on the basis of selected recognitions, where the communal element is noticed, as well as, the motives of getting involved in the practice of cooperative action. In the cognitive variant created by myself, I shall attempt to identify the traces of „social linking” referred to the modern man (individual following modernity).

\section{Post-modern inspirations}

Within the diagnoses of the state of the post-modern society, or the society of the „second” or late modernity (Bauman, 1996, 2000, 2011; Beck, Giddens, Lash, 1996; Giddens, 2008), within the reflection emphasising on the „individualised society”, „society of individuals” (Bauman, 2008b; Elias, 2008) one of the key terms is individualisation (conceptualised as a structural process and a form of socialisation, specific for a contemporary society) (Beck, 2004; Beck, Beck-Gernsheim, 2006; Giddens, 2002, 2003).

Individualisation - as noted by Ulrich Beck - means to liberate from the historically determined forms and social ties, where we may notice the loss of traditional security measures regarding the way of acting, faith, and crucial norms. According to the author, individualisation had currently become a structural fact, forced onto people by the system, not chosen but destiny. The fact, how a given individual lives is simply a biographical solution of systemic limitation. In an individualised society, the individual is forced to decide on every aspect of own life and make the effort in order to build own biography („biography of choice”, „reflective biography”), becoming own point of reference („a planning office of own biography”) (Beck, 2004: 202-203).

In specifying the individual that is using own resources, it is advisable to turn attention to the thought by Jean-Claude Kaufmann, referring to the status of a democratic individual, developed progressively: „What we are currently observing (the democratisation of the private life), opens new horizons. The individual chooses own truth, own morality, own social relationships and own identity" (2004: 229).

An important issue, presented by the theoreticians of modernity or post-modernity for the purpose of scientific reflection, consists of interpersonal relations changing under the influence of the individualisation process. Interesting analyses 
become the basis in the characteristic of the current status of the relation between the individual and the social environment. Based on them, one may attempt to construct their image, one of many. Therefore, inquire about the consequences, e.g. structural individualisation within the social plane, without particular attention to the cultural one (Jacyno, 2007).

A successful process of pursuits within this area may lead, i.a. to one of the most significant diagnoses regarding the impact of individualisation processes on social relations, contained in the work titled The Homeless Mind (Berger, Berger, Kellner, 1973). Its authors - interested in the existence of an individual in the world, the important element of which being how the „world" is expressed in their consciousness, claim that individualisation brings liberty and independence, and these come at a cost, being the loss of stability and stable points of reference. The phenomenon of the constant increase of anonymity of social relations, to which technological development and new economy contribute, is accompanied by the loss of meaning and sense in interpersonal relations, that are no longer obvious and integrative, but may be a source of fear and threat. In modernity that transforms man in a constant „wanderer" between numerous world, the reality of which is relative (what seems obvious now, may not be obvious tomorrow), modern individual is as a homeless person in a modern city: unsure of its place (according to the suggestions made by the authors) (Mikołajewska, 1999: 283).

Conceptualisation of individualisation is tied (brought about by) to a new free space giving more freedom of acting and organising own life. In the reflective trend of organising it, the individual is liberating itself from own ties that bind it. „Rooted out” from the existing structure, constituted by traditional social forms (including family), the individual is located within a new reality, where it its ties and created forms appear to be increasingly free and coincidental, presenting themselves as a minor nuisance that can be easily discarded. One could say, by using the words of $\mathrm{Z}$. Bauman, that we are witnessing the appearance of „peg communities” (Bauman, 2008a: 97), explosive communities - „locker room” and „carnival” (Bauman, 2006: 311).

The social ties of the individual should not interfere with its ability to answer convincingly to questions regarding existence: „,... [ related to basic parameters of human life, to which everyone "responds” who 'manages' in social circumstances; they include the following ontological and epistemological elements: existence and being; the nature of existence, the identity of things and events; the finite nature of human life; existential inconsistency being that human persons are a part of nature, and simultaneously, they differ as rational and reflective beings; the experience of others; how individuals interpret features and actions of other individuals; identity 
continuity; the continued feeling of being a person bound by the continuity of the experience of „self” and own body” (Giddens, 2002: 78).

The belief of an individual regarding the fact that the surrounding world is cognitively and axiologically tameable (stable?) not only does not encourage orienting around oneself, but also strengthens "sharing the world with others”, sensitises for harmful phenomena (from the individual viewpoint). It favours filling the world with possible, in terms of "experimental games" undertaken by the individual, lifestyles and ways of acting. Therefore, struggling to remain at peace with self, find oneself with retaining clear references to that which is „always given to us", with the potential to correct that which is touched by erosion (institutions that give the sense of belonging, social ties).

One must note, that the association of views presented by A. Giddens with the image of the "post-modern” world of Z. Bauman, particularly with the „postmodern personality” "does denote great chances for being - for", signalling radical turns within the plane of values and morality. The "post-modern personality” constituted by the features of personal models of a stroller, vagabond, tourist and player (to use the well-known metaphors of the authors) (Bauman, 1994) becomes more of a subject of aesthetic and consumption evaluation, rather than moral one. The dominating new „social personality” stands before a narrowed scope of interacting with others, the emotional and active engagement in the fate and needs of others weakens, and ethical reasons, as well as, moral sentiments are being suppressed. The way of „being-in-the world” perpetuating in „post-modernity” pushes the individual "towards considering them as obstacles and limitations, which should be overcome due to the consequent realisation of a life strategy" (Bauman, 1995: 105-106). Moreover, less and less space is reserved for established norms and ethical principles, and more space for individual choices.

It is no coincidence that the creation of a peculiar type of a modern man is supplemented by the "modern personality” syndrome, where one of the main themes is the feeling of subjective power (Bauman, 1994). As there is no coincidence in saying that "the subject gradually shrinks to the sole point of I. distancing from own social relations, and from performing acts. All relations, and even all qualities remain outside. They are all deprive of a constitutive meaning" (Rosa, 2016).

A separate meaning is brought about turning attention to the fact, that in the notes by Anthony Giddens, a construct of a „pure relation” (Giddens, 2002: 122), appears, as a relation that gains a character of temporariness referring to emotional potential, which constitutes close relations, however, can lose the function of providing the feeling of safety at any time. The specifics of the „pure relation”, apart from the fact that it is constituted solely within the emotional plane of the human, 
is to achieve mutual trust and intimacy. It is also inscribed with a state of uncertainty, strengthened by modernity perceived as unexpected: „Life in the world of a highly developed modernity is like a tycoon. It is not only about the constant changes. The essence lies in the fact, that these changes transgress all expectations of the man and dodge his control" (Giddens, 2002: 40).

Therefore, the auxiliary task of exposing the "individual in modernity" is tracking the traces of modern man's pursuits: some kind of his belonging, searching for fellow men, relations with them. In other words - a code which reappears in social discussions such as the concept of participation (a phantom to some, hope to others).

In order to indicate the path towards social integration, with full awareness of the fact, that civic virtues are no longer perceived as indicators of social action, that people live in groups, that combine various social ties (Rejman, 2007) accompanied by the need - as noted by Z. Bauman - „clear pointers leaving no doubt, clear maps and straightforward guidelines” (1994: 39). „More than ever - U. Beck supplements to a degree, we need concepts, that [...] referring positively to every treasure of tradition, would allow us to think in a new way, about the new that appears before us. Additionally, a new way of living and acting. However, grasping these concepts that appear today, during the fall of others, is a highly difficult task" (Beck, 2004: 18-19).

In search of ways of achieving social integration of individuals of post-modern identity, treating communities with reserve, as they bind their members with formal norms, participation and loyalty rules, discarding traditional identification objects, avoiding commitment and attachment to people and places, interpersonal relations based on trust are noted. The feeling of trust seems to be the key to solving problems which must be tackled by contemporary societies, demanding, as if perversely against their dominant spirit, some order, a relative constancy and universality of collective life.

Within this context, the positive message of post-modernity is that contemporary democracies in the face of favouring the interest of an individual over the common good, in the face of a falling welfare state, are searching for means of achieving a higher level of involvement and mutual responsibility of all citizens regarding social life (Szacki, 1997). Readiness for a responsible involvement in the social life should be based primarily on trust, as confirmed by J. Coleman, R. Putnam. According to both authors ${ }^{1}$ social capital expressing in the form of trust

${ }^{1}$ One must note, that between the Putnam theory of social capital, and Coleman's theory, there are differences the primarily result from the context of analysis, in which both scholars are using the term „social capital”. 
implicates mutual collaboration of the members of the society for the common good. Trust, as well as, norms and relations considered by them as the components of social capital may increase the efficiency of a society, allowing for coordinated action (Putnam, 1995: 258).

Building trust in society conditions of late modernity is achieving a new quality, as it requires, i.a. „democratisation of democracy”, which, for A. Giddens means, that all spheres of life are regulated by dialogue, and not by previously established relations of power ${ }^{2}$.

\section{References to education}

Using the proposed way of thinking - for myself it is important, that the contemporary understanding of the fact is the "co-existence and existing for others” allows to formulate notions (not to say - doubts) inspired by selected cognitive categories. These are, without a doubt, pure relations, trust and dialogue. The concepts may turn out to be guidelines on the path of agreement in the atmosphere of solidarity, a "chance for a civic modernisation via education".

The opportunity becomes obvious and understandable, when we are dealing with a version of society, that is inclined towards reflection regarding the necessity of perfecting the conditions of life by the populace, via education. We are getting better at determining particular trends, we adopt strategic educational mottos, „knowledge society”, , active citizenship”, ,investing in human capital”.

It is a clear challenge for education, as it, in combination to heuristically useful slogans of education, "trust-based communities are reduced to the fact, that the community established in education that co-accomplishes democracy, is one of the forms of organisation of life, that would provide all participants with the opportunity to take part in pure relations" (where trust is not and cannot simply be a "premise"), therefore pure chances for the development of individual potential on the basis of mutual trust. The decisive role should fall on relations of social acknowledgement, strengthening the individual autonomy and opening for organisation, dialogue, and readiness towards cooperation.

An important task for education is to prepare for community, life and acting under the conditions of ,the existence of a network of affective relations within a group of individuals, that often intertwine and strengthen each other" (Etzioni,

\footnotetext{
${ }^{2}$ A more expanded explanation of what Giddens refers to as democratisation of democracy in: Giddens, 1999: 66.
} 
2010: 190) and the occurrence of „identification with common values, norms and meanings, as well as, with common history and identity - in other words, common culture" (Etzioni, 2010: 190). All the above should merge, automatically to a degree, in a constructive shape of a society - advocating for democratisation of life, including education.

Here, one should add the important fact in understanding contemporary education. Starting with thoughts noted by T. Pilch, that it is highly insufficient to understand democracy as a representative system, its essence is not exhausted by universal and high competencies, with the essential outline of the contemporary education being "the art of building local and global community of men and the ability for a trustworthy coexistence in such a community [...] universal feeling of responsibility for the fate of the community and the fate of the weak" (Pilch, 1996: 77). In the concept of democracy, we find a founding point for the „new contemporary" we may find the direction of pursuits, on the line of which we achieve a better understanding for being together, mutual action, which will save education from the appearances of social integration.

Considerations regarding education that would realize the democracy formula expressed by a phantasm of community, where ties based on trust and mutual care are formed (community not „infected” by the progress of individualism currently) one should refer to the reality of the Polish society, the development of which in many parts of history, would stray from the main path of development of social societies, and did not complete the process of modernization (Marody, Wilkin, 2003). Therefore, the necessity arises, or considering the issue of achieving and implementing communities in education, communities, the members of which may trust each other, consciously cooperate for the common good, which should benefit democracy further, as it badly deals with the tensions caused by social inequalities.

Along with the question regarding the possibility of education towards democracy, built of a bind and community building element, an attempt may appear, to answer the question whether we see in our country, a democratically founded culture of responsibility for education, that would both secure autonomy that obligates towards liberty, and integrate all entities within education (participation in community), implicating „equality as justice”. In the enquiry regarding the edu-

\footnotetext{
${ }^{3}$ According to E. Potulicka: „In the case of equality as justice or fairness it is not about equal access to schools, or equal opportunities, but about the principle of just redistribution of resources, whether material or abstract (e.g. power or status). The principle implicates the potential of existence of inequality tied to giving unto others more than they give themselves" (1996: 176). Here, it is worth mentioning the parable brought about by social scientists regarding talents, taken from St. Matthew:
} 
cational experience of democracy, one cannot omit attention towards „the community of relation" referring to the internal interdependence based on sharing the same interests, issues, hobbies and values (Lave, Wenger, 1991). It is important to speak of sharing values, not only when they are related to „survival” and success of teachers, students and parents related to the aim. Without changes in the mentality of education participants, established attitudes, learned (often comfortable) models of their actions, it is difficult to achieve "reflective democracy” necessary for „learning the art of democracy” (King, 1979).

To put it briefly, with the issue of an educational community inscribed in the process of systemic transformation, we open a new page of democratic changes realised in not always transparent, newly established planes of the social life, in situations demanding realising many rules of the game, as well as, how resources allowing to participate in the currently existing "game” are used. To elaborate on the matter metaphorically, not everyone entered the game, despite the universal call. Still, „democracy under Polish circumstances is realised in an actually nontransparent social plane, causing the appearance of chaos, in which education was (is) subject to the game of interests of institutionalised authorities, orientation of multi-party politicians, as well as, the resistance from teachers and parents against (alas!) initiatives of subjectification, and socialisation of the school"4. A serious obstacle in changing school towards its socialisation (which is the main theme of the reform of the educational system, initiated in 1999), introducing "team work game” of all interested in the „coming-to-be of the new”, turns out to be the stereotypical approach towards the thinking of the role of parents in the educational system, still considered in strict terms, within boundaries denoted by the habits of the old system.

Despite clear orientation on subjectivity and partnership in education, persistent emphasis on the meaning of integration, authentic cooperation of all parties involved, actual functioning of the actors of the educational scene, it is still progressing according to old rules. Subordinate parents are still kept at a distance. They appear as co-hosts, still dominated in actuality, within the scope set out by the teachers. In result, the opportunities of creating own community are very limited.

Obviously, the situation is much simplified ${ }^{5}$ and generalised, separated from positive exceptions (with no division between groups of different interests). Its

\footnotetext{
„For unto every one that hath shall be given, and he shall have abundance: but from him that hath not shall be taken away even that which he hath" (Mt, 25) (Zahorska, 2009: 196).

${ }^{4}$ Diagnosis of education posed on the VII Convent of PTP delegates, Warsaw, 11 April 2002. Quote after: Rodziewicz, 2009.

${ }^{5}$ I have used but some analyses by Mendel, 1998, 2000, 2006.
} 
aim is to clarify this part of education, which encourages hesitation regarding the current conditions, the ability of creating an educational community - the one that is actually functioning, the value for which would be the diversity of parent and teacher culture.

Finally, one could be tempted to state, that the building of an educational community in our reality (Polish society subject to transformation and integration), benefit from the changes leading to the adaptation of rules considered as key and universal in Western countries, perceived via the scope of their developed democracies. Maturing towards it, by the transforming Polish reality, strengthened by filling our already liberal democracy with vitalising rationalities, post-structural intellectual trends, the perspective of humanistic philosophy, phenomenological pursuits, are made visible, e.g. by departing from state education towards various form of education: private, social, local government (Rodziewicz, 2008). Additionally, the actions for the renewal of education in the significant participation of these forms of community, which are structured democractically and help realise democracy as one of the forms of life organisation (hopes brought up by J. Dewey) (1996).

The very acceptance of the path towards Western democracies, an already existing area of universally accepted regulations in the increasingly popular practice of common, cooperative action does not decide on the democratisation of education, which still remains an incomplete democracy, with a peculiar game of appearances (Szymański, 2005). Scepticism against respecting the rights and liberties of educational entities - active, solidary, communicating, supposed to accomplish the postulate of the democratisation of social life via own actions, remains. There is still a deficit of participatory democracy, confirmed with the lack of participation in bottom-up movements, third sector organisations regarding people who experience exclusion, that have no feeling of impact, resultant of the lack of the skill for spontaneous organisation in order to achieve certain, often locally specified tasks. Interestingly, the division between those with a subjective feeling of exclusion and having the feeling of impact on the course of events (causality) is not located within the classic industrial conflict, but it is represented by individuals from varying social categories (Domański, 2005).

In the light of the „Polska 2050” report, the Polish society entered a trajectory which was in effect (partially still is) in countries that belonged the Euro-Atlantic civilisation with its particular traits, i.e. individualism, differentiation, rationalism, economism and expansiveness without deciding on the mean of acquiring the traits; and some changes have been noted confirmed with the new structuring. Along with the thought of the presented position, attention is turned particu- 
larly towards: polarisations between the „victors” and the „defeated” in result of transformation, as well as, the openness of the structure, characterised by relative openness towards achieving social status (via increased social mobility and educational opportunities) and the meritocracy degree in the processes of distributing resources (to what degree the adequacy between resources at disposal of individuals and their socially recognised and legitimate „merits” occur) (Komitet Prognoz, 2011: 94).

From these briefly presented traits that constitute the image of changes occurring in the social structure under the impact of transformation processes, one may conclude, that the condition for social modernisation which is the differentiation of the society, was met. However, the differentiation - progressing but „impeded” is accompanied by „inefficient democracy” allowing for the emergence of areas of perpetual poverty, and social marginalisation of groups that are not rooted in the network of social relations network of formal character. Additionally, it is difficult to conclude, whether we are already a society in which every individual has the same opportunity of achieving the desired position and goods, and whether the realisation of the aforementioned depends on its own merit (not excluding that which was inherited). Many individuals are unable to properly recognise and evaluate own chances, cannot learn the paths leading to improving own fate, not to mention any type of success ${ }^{6}$.

\section{Final remarks}

There is no doubt that the "democratic social order is an educational task for us" (Kwieciński, 1995). The question „Is there a place for democracy as a value in Polish education, meaning: participation, justice, equality, joint decisions, working in groups, cooperation, division of power, strengthening social roles, mutual respect and diversity, otherness?" (Śliwerski, 2013) requires continual analyses (without the assurance of gaining confirmation). Importantly, posing the problem itself, secures us from the trap of wishful thinking, following signals, the beginnings of certain tendencies to be considered as undeniable evidence, indicating at the existence of desired phenomena in full, already developed form. Therefore, we remain in a situation of the enquiry on democracy, resulting from the perpetual creation and definition of the realist, who „has been used not to begin pursuits for what to

\footnotetext{
${ }^{6}$ The issue of differentiating our society is presented by my using a number of „mental leaps”, taken from M. Ziółkowski’s analyses (2005). Quote after Leszkowicz-Baczyński, 2002; Marody, 2004.
} 
do in order to make it perfect, but with, how and to what degree we should change, to adjust the reality to the most urgent need" (Kotarbiński, 1987: 127). We engage in "reflectiveness" in order to deal with this new "modernity” with clear tendency for „individualisation”. Let this reflectivity lead us to a community as a desired form of our existence, despite the foretold atmosphere of loneliness.

\section{Bibliography}

Bauman Z. (1994), Dwa szkice o moralności ponowoczesnej, Warszawa.

Bauman Z. (1995), Ciało i przemoc w obliczu ponowoczesności, Toruń.

Bauman Z. (1996), Etyka ponowoczesna, Warszawa.

Bauman Z. (2000), Ponowoczesność jako źródło cierpień, Warszawa.

Bauman Z. (2006), Płynna nowoczesność, Kraków.

Bauman Z. (2008a), Wspólnota. W poszukiwaniu bezpieczeństwa w niepewnym świecie, Kraków.

Bauman Z. (2008b), Zindywidualizowane społeczeństwo, Gdańsk.

Bauman Z. (2011), 44 listy ze świata płynnej nowoczesności, Kraków.

Beck U. (2004), Społeczeństwo ryzyka. W drodze do innej nowoczesności, trans. S. Cieśla, Warszawa.

Beck U., Beck-Gernsheim E. (2006), Individualization. Institutionalized Individualism and its Social and Political Consequences, London.

Beck U., Giddens A., Lash S. (1996), Reflexve Modernisierung - Eine Kontroverse, Frankfurt am Main.

Beck U., Giddens A., Lash S. (2009), Modernizacja refleksyjna: polityka, tradycja i estetyka w porząku społecznym nowoczesności, trans. J. Konieczny, Warszawa.

Berger B., Berger P., Kellner H. (1973), The Holmes Mind. Modernization and Consciousness, New York.

Dewey J. (1996), Die Öffentlichkeit Und Imre Probleme, Bodenheim (original edition 1927).

Domański H. (2005), Państwo to nie my, „Polityka”, no. 2533.

Elias N. (2008), Społeczeństwo jednostek, trans. J. Stawiński, Warszawa.

Etzioni A. (2010), Wspólnota responsywna: perspektywa komunitariańska, in: P. Rymarczyk, T. Szubka, Komunitarianie. Wybór tekstów, trans. P. Rymarczyk, Warszawa.

Giddens A. (1999), Trzecia droga. Odnowa socjaldemokracji, trans. H. Jankowska, Warszawa.

Giddens A. (2002), Nowoczesność i tożsamość. „Ja” i społeczeństwo w epoce późnej nowoczesności, trans. A. Szulżycka, Warszawa.

Giddens A. (2003), Stanowienie społeczeństwa. Zarys teorii strukturacji, trans. S. Amsterdamski, Poznań.

Giddens A. (2008), Konsekwencje nowoczesności, trans. E. Klekot, Kraków.

Jacyno M. (2007), Kultura indywidualizmu, Warszawa.

Kaufmann J.-C. (2004), Ego. Socjologia jednostki. Inna wizja człowieka i konstrukcji podmiotu, Warszawa.

King E.J. (1979), Demokratyzacja szkolnictwa średniego, in: Oświata i wychowanie w toku przemian, ed. A. Mońko-Stanikowa, Warszawa.

Komitet Prognoz „Polska 2000 Plus” (2011), Polska 2050, Warszawa.

Kotarbiński T. (1987), Pisma etyczne, Wrocław. 
Kwieciński Z. (1995), Demokracja jako zadanie edukacyjne i problem dla pedagogiki, in: Pedagogika alternatywna - dylematy teorii, ed. B. Śliwerski, Łódź-Kraków.

Kwieciński Z. (ed.) (2009), Wychowanie w społeczeństwie permanentnego kryzysu, Toruń.

Lave J., Wenger E. (1991), Situated Learning, Cambridge.

Leszkowicz-Baczyński J. (2002), Społeczeństwo posttransformacyjne: fakt społeczny czy niespełnione marzenie?, in: Stary kontynent w nowym tysiącleciu, ed. Z. Drozdowicz, Poznań.

Marody M. (2004), Przemiany więzi społecznych $i$ ich konsekwencje dla sfery publicznej, in: Zmiana czy stagnacja?, ed. M. Marody, Warszawa.

Marody M. (ed.) (2019), Społeczeństwo na zakręcie. Zmiany postaw i wartości Polaków w latach 19902018, Warszawa.

Marody M., Wilkin J. (eds.) (2003), Na prostej? Polska w przededniu członkostwa w UE, „EU-monitoring", VII.

Mendel M. (1998), Rodzice i szkoła. Jak współuczestniczyć w edukacji dzieci?, Toruń.

Mendel M. (2000), Partnerstwo rodziny, szkoły i gminy, Toruń.

Mendel M. (2006), Miejsca rodziców w przestrzeni szkoły, in: Pedagogika miejsca, ed. M. Mendel, Wrocław.

Mikołajewska B. (1999), Zjawisko wspólnoty. Wybór tekstów, New Haven.

Pilch T. (1996), Programowy i organizacyjny kształt przyszłej szkoły, in: Demokracja a oświata, kształcenie i wychowanie. Materiały z II Ogólnopolskiego Zjazdu Pedagogicznego, eds. H. Kwiatkowska, Z. Kwieciński, Toruń.

Potulicka E. (1996), Szkoły samorzadne czy zdominowane? Lokalne zarządzanie szkołami w polityce oświatowej anglosaskiej nowej prawicy, in: Demokracja a oświata, kształcenie i wychowanie. Materiały z II Ogólnopolskiego Zjazdu Pedagogicznego, eds. H. Kwiatkowska, Z. Kwieciński, Toruń.

Putnam R. (1995), Demokracja w działaniu, Kraków.

Rejman K. (2007), Kapitat społeczny w teorii społeczeństwa obywatelskiego, in: Społeczeństwo obywatelskie. Modele teoretyczne i praktyka społeczna, ed. E. Balawajder, Lublin.

Rodziewicz E. (2008), Ku demokracji w sferze publicznej i dyskursie edukacyjnym. Polskie Towarzystwo Pedagogiczne wobec zmiany społecznej, „Ars Educandi”, vol. V.

Rosa H. (2016), Resonanz. Eine Soziologie der Weltbeziehung, Berlin.

Szacki J. (ed.) (1997), Ani książę, ani kupiec: obywatel, Kraków.

Sztompka P. (2012), Socjologia. Analiza społeczeństwa, Kraków.

Szymański M.J. (2005), Nierówności społeczne w polskim szkolnictwie, in: Edukacja - szkoła - nauczyciele. Promowanie rozwoju dziecka, eds. J. Kuźma, J. Morbitzer, Kraków.

Śliwerski B. (2013), Polska edukacja wobec demokracji jako idei, wartości, ustroju, Warszawa.

Środa M. (2003), Indywidualizm i jego krytycy. Wspótczesne spory między liberałami, komunitarianami i feministkami na temat podmiotu, wspólnoty i płci, Warszawa.

Zahorska M. (2009), Edukacja drogą do marginalizacji?, in: Sprostać zmianom. Szkice o powinnościach wspótczesnej socjologii, eds. K. Slany, Z. Seręga, Kraków.

Ziółkowski M. (2005), Utowarowienie życia społecznego a kapitały społeczne, in: Kręgi integracji i rodzaje tożsamości. Polska. Europa. Świat, eds. W. Wesołowski, J. Włodarek, Warszawa. 
